\title{
Enter centre stage, the case study...
}

Dr Deborah A. Lee

Senior Lecturer in Sociology

Division of Sociology

School of Social Sciences

Nottingham Trent University

Nottingham

NG1 4BU

Telephone: 01158485588

Email: Deborah.Lee@ntu.ac.uk

\section{Biographical note}

Deborah A. Lee is Senior Lecturer in Sociology at Nottingham Trent University, and she is completing person-centred and experiential psychotherapy training at the Sherwood Psychotherapy Training Institute (SPTI) in Nottingham. Deborah's research/teaching interests increasingly bring together sociology/psychotherapy. Deborah is on the Steering Group of Psychotherapists and Counsellors for Social Responsibility (PCSR), editor of the PCSR journal Transformations, an Associate Editor for Psychotherapy and Politics International, and a member of the UKCP Ethics Committee.

Acknowledgements: The author would like to thank Glenda Melville, Deanne Gardner, Ambika Erin Connelly, Michelle Cooke, Michelle Oldale, Suzanne Keys, Jason Wood, and, of course, Kate Smith.

Disclosure statement: The author declares no financial interest or benefit arising from this research. 


\section{Abstract}

This existentially-informed person-centred paper argues that current conceptualisations of 'case studies' (beloved of psychotherapy training and beyond), can reduce complex/beautiful human beings to flat/objectified characters defined by 'presenting problems' - 'presenting problems' which clever therapists 'fix'. In response, the paper develops an arts-based approach: a collaborative, respectful/ethical, narrative 'case study', written as a play - a piece of public psychotherapy available for the audience's responses. The play seeks particularly to convey the warmth of encounters between two rounded/unique characters, Deborah and Kate, offering a challenge to the 'us' and 'them' approach of many 'case studies'; it contends that if this is achieved, it is this rather than narrow/sterile advice about 'assessment', 'formulation' and 'interventions' - which establishes the usefulness of the work.

Keywords: case study; person-centred; existentially-informed; narrative approach; arts-based; psychotherapy training. 


\section{Enter centre stage, the case study...}

\section{Prologue}

\section{Narrator:}

'Prepare to welcome the "case study"!

A fictional/academic/ethnotheatre hybrid!

A "narrative approach" - person-centred and existentially-informed!

Magical encounters in relational ethics and shared humanity!

A public psychotherapy for the stage!

Playwright's notes: A name in bold means that person is on-stage; more than one audience member is being signified by $\mathbf{A M}$; artistic licence has been taken with the cast!

\section{Act 1}

(The curtain rises.)

McLeod (2010), standing in a spotlight, muses: 'There has been relatively little methodological innovation within the narrative approach...' (p. 27).

Zeldin (2015) enters, observing: 'Each meeting between two people that is not merely superficial is an opportunity to enlarge [life] beyond the banal, through discovery and invention' (p. 395). 
Bourriaud (1998) (introduced with a flourish by Jones, 2006, p. 72) takes both their hands, and declares: 'Relational art...[is] a set of artistic practices which take as their theoretical and practical point of departure the whole of human relations and their social context' (p. 133).

('Clinical' bright light blinds the audience; it's freezing cold...)

Voice off: 'It's the CASES!'

The 'cases' enter; signs covering their faces.

'l'm borderline'

'I'm depressed'

\section{'I'm anxious'}

... 'I'm a healthy control's' sign doesn't obscure his smile.

(The lights soften. The cast list appears on-screen.)

'The "case" - forty-six+ audio-recorded fifty-minute encounters, between Kate Smith (a self-chosen pseudonym) (38, female, heterosexual and in a relationship) (the "client") and Deborah Lee (44, female, heterosexual and in a relationship) ("the psychotherapist-in-training"). In the wings, an experienced/enigmatic female supervisor (her choice of words). All encounters are UK-based'.

'And here, a supporting cast of many (Ayckbourn's [2002] rule that 'economy often equals better art' [p. 13] is cast aside!")'

(The screen displays the following.) 
'Assessment of the "presenting problem"? People are "a dynamic flow, continually changing over time" (Cooper, 2015, p.55). Worsley (2006) says of Levinas: "we cannot know others or ourselves for we are creatures of inexhaustible possibility" (p. 213).

Ayckbourn (2002) interjects: 'A good DSM is like gold' (p. 157). The only DSM here is the Deputy Stage Manager!

The intervention? ‘Dialogical exchange’ (Cooper, 2015, p.73).

How was the case study done? It was a collaboration.

The outcome? The relationship is ongoing; Kate's judgement is paramount."

AM: 'She's...HUMANISED the case! She doesn't know how to do assessment and formulation! Where's she studying?'

Two cognitive-behavioural therapy (CBT) therapists, Shorey \& Stuart (2012) read from their assessment/formulation: 'Henry' was a 26-year old, single, nonHispanic Caucasian male who was self-referred...for possible treatment for symptoms related with anxiety. Henry lived alone, was employed part-time as a cashier at a local retail company and was also a full-time student.... Henry's presenting diagnosis was SAD ['social anxiety disorder']. The therapist was a $2^{\text {nd }}$ year male undergraduate student in clinical psychology supervised by a licensed clinical psychologist' (p. 36).

Shorey \& Stuart (2012) add: 'He reported living alone...' (p. 37).

AM: 'We heard you the first time'. 
Shorey \& Stuart (2012) continue, after treatment: 'he was currently engaged to be married' (p. 44).

AMs: 'Didn't you do well!'

The therapists smile.

Cooper (2003) shakes his head: 'It-ification' (p. 134).

Friedberg, Tabbarah \& Poggesi (2013) object, declaring 'presence' ('a way of being' which 'enables authentic connection' [Tannen \& Daniels, 2010, p.1]) important in CBT: when 'therapists add presence, immediacy and transparency...increased patient involvement and therapeutic momentum is likely to be realised' (p. 2).

AM: 'Feels like a technique'.

Person-centred therapists, Stephen, Elliott \& MacLeod (2011) share 'their' social anxiety case. 'Lucy....was 40 years old. ...A Scottish female, living alone, Lucy was employed in a professional role... The therapist assigned to work with Lucy was trained as a psychologist and a PCT psychotherapist, with 12 years' post-training experience' (p. 57-58). After therapy, 'she had developed a lasting relationship'! (Stephen, Elliott \& MacLeod, 2011, p. 60).

(Confetti rains down.)

AM: 'Was Lucy white? How old was the psychologist?'

A voice off muses: "presence" was probably there in the encounter with "Lucy", but it feels like the "clinical case study's" structure jars with person-centredness?' 
'Yes!' says Madison (2010): 'The pathology-centred form of encounter gives rise within psychotherapeutic literature to medical attitudes expressed in adjectives such as "clinical". [Then] the therapist takes an objective quasi-physician role in order to deliver the experimentally derived intervention' (p. 194).

Deurzen (2010) tweets: 'existential therapy does not consider anxiety to be evidence of pathology, but rather an essential reminder of our vibrant and dangerous aliveness' (p. 238).

AM: 'McLeod (2010) says "it is the most troubling, embarrassing or shameful aspects of [a client's] life that are being most closely scrutinised [in a case study]" (p. 54), so maybe there's better to come...'

MacLeod \& Elliott (2014) muse that the 'skeptic' stance of their hermeneutic single-case efficacy design (HSCED) studies ... may be problematic '[because] the client may access and read public accounts of their experience' (p. 308).

McLeod (2010) concurs, clients 'may discover what their therapist really thought about them' (p. 55).

(Offstage, women laugh.)

A psychodynamic therapist, Jacobson (2000) introduces the 'case' of 'Pierre': '[My supervisor said] "I should let him leave if he needed to, since two years is about as long as these kinds of borderlines remain in treatment"' (p. 4).

Geller \& Greenberg (2012) assert that psychodynamic therapy 'emphasise[s] the importance of creating a lively, genuine relationship with the patient' (p. 20) to effect change. 
AM: "The "genuine relationship" sounds good... But "these" borderlines? Are we seeing how the "clinical case study" can objectify? Is this ethical? Does it prize diversity? Is this what psychotherapists-in-training need to hear?'

Leavy (2015) says that arts-based research (ABR) work (like this) can jar people into seeing and thinking differently' (p. 25).

(It starts warming up.)

\section{Narrator:}

'We've started to see "case studies" questioned, with regard to diversity (or "intersectionality" - Collins \& Bilge (2016) explain that "power relations are to be analysed both via their intersections...as well as across domains of power, namely structural, disciplinary, cultural and interpersonal" (p .27) and "relational ethics" ("a co-constructed ethical and moral encounter, with associated relationship experiences and processes, that both influences and in turn is influenced by the complex multidimensional context in which the relationship occurs" [Gabriel \& Casemore, 2009, p. 1]), so let's take a closer look at "case studies".

McLeod (2010) identifies five "genres" (p. 17): (i) "single subject studies...an observable and measurable target behaviour would be identified, and the frequency of this behaviour would be monitored" (McLeod, 2010, p. 19); (ii) "theory building case studies" (McLeod, 2010, p. 21); (iii) "pragmatic case studies [in which] the practitioner is required to collect as much information as he or she can on a case" (McLeod, 2010, p. 24); (iv) "HSCED studies... [which ask] is this a good outcome case? Can the outcome be attributable to therapy?" (McLeod, 
2010, p. 26); and (v) "narrative case studies... [which look at] what the therapy was like" (McLeod, 2010, p. 27). In addition, there have been "autobiographical and fictional narrative case studies" (McLeod, 2010, p. 203), which haven't been received with great interest (McLeod, 2010, p. 204).

"Single subject studies" raise questions in viewing a case "as if it were an experiment" (McLeod, 2010, p. 20); "theory building case studies" challenge therapists who fear questioning "conceptual edifices" (McLeod, 2010, p. 23); "pragmatic case studies" imply that there are "different types of client" (McLeod, 2010, p. 25) when Worsley (2006) draws on Levinas to talk of people as "infinite" (p. 218); and the "judicial framework" (McLeod, 2010, p. 26) of HSCED studies makes the client "a key witness" (MacLeod \& Elliott, 2014, p. 296) rather than the judge. Of the "narrative approach", McLeod (2010) says "much more needs to be done, in terms of method development..." (p. 206) or work may be unpublishable. As we saw just now, "case studies" can reduce clients to first names, their identities encapsulated selectively - and meaninglessly. That "Lucy" is "40" (Stephen, Elliott \& MacLeod, 2011, p. 60) signifies nothing in the text. People become "presenting problem(s)" which clever therapists (identified by their experience) "fix" - preparing them for (more) social control. For is a "lasting relationship" (Stephen, Elliott \& MacLeod, 2011, p. 60) really the pinnacle of therapeutic success? Are we hearing a distasteful suggestion that "Lucy" was gathering dust? Samuels (2015) talks of psychotherapy's "fairly bad record" (p. 9) in relation to "diversity".

McLeod (2010) explains that: "there has been little work on case study ethics" (p. 58). Therapists' decisions must not just be about "ethical procedures" advises 
McLeod (2010, p. 71) but about "moment-by-moment ethical decision making". Carroll \& Shaw's (2013) conceptualisation of "ethical maturity" (p. 137) - to be able to make/implement "good or better" decisions, to take responsibility for them, and to learn/grow from them - involves "relational ethics": "with such importance on human relationships for life, development, growth and happiness, is it any wonder that a relational ethics should find its way into the heart of ethical maturity?" (Carroll \& Shaw, 2013, p. 103).

The narrative/ABR approach offers a relationally-ethical approach which respects complexity. Leavy (2015) defines ABR as "an engaged, moral, and at times political activity" (p. 29). Leavy (2015) contends that public ABR can generate "empathy" and "self-reflection" (p. 2). Willis et al (2014) says that this sort of approach is now "attracting increasing attention in the field of counselling and psychotherapy" (p. 526), citing Meekums' (2011) special issue of the British Journal of Guidance and Counselling as one example. Speaking of ethnotheatre, Saldana (1999) explains that only editing which "will not affect the integrity of the voice or quality of the data" (p. 63) is permitted. This is what Deborah has done here. Such work calls for "new and more ambiguous [evaluation] criteria" (Gergen \& Gergen, 2011, p. 8). Leavy (2015) declares that "usefulness" (p. 27) is highly important.

Deborah is committed to the British Association of Counselling and Psychotherapy's (BACP's) (2016) ethical principles: being "trustworthy", "[respecting] the client's right to be self-governing", "promoting the client's wellbeing", "avoiding harm to the client", being "fair" and self-caring (p. 2). There was "no inducement or pressure" (McLeod, 2010, p. 64) for Kate to participate 
(informed consent for the work went through two negotiated iterative informed consent forms). The "ongoing" (Abrahams, 2007, p. 241) nature of Kate's consent was recognised.

Bond (2013) refers to an "ethically mature" research as involving "discussion with clients" (p. 339), but he doesn't suggest collaborating. MacLeod \& Elliott (2014) refer to a client undergoing a "battery of quantitative measures" (p. 296), which sounds like an imposition. Here, Deborah and Kate spent time dialoguing about their relationship (prior to, or after therapy sessions). For one dialogue, "helpful/unhelpful" events (Elliott (1999, p. 307) was used. All dialogues were audio-recorded (McLeod, 2010, p. 69), with consent; material selectively quoted was transcribed, and approved by Kate. Kate approved the final version of the work.

As the focus is upon process, personal material was kept minimal. While "intersectionality" demonstrates "complexity", revealing all of anyone's identity jars with ethics: instead, Kate chose how she wished to be described, and Deborah mirrored her choices. There are some personal identity similarities evident in these descriptions (above) but clearly Deborah and Kate are different (Lago \& Christodoulidi, 2013, p. 116), and the social structures in which they are located matter even if they are not explored here in order to be respectful of ethics.

Deborah feels this approach is consistent with her therapy room encounters. Adame \& Leitner (2011) point out that Buber's meaning of "dialogue" is "literal spoken conversation but also how our choices and actions in life are a way of 
dialoguing or being-in-the-world" (p. 44). She follows Yalom (2002), seeing client/therapist as "fellow travellers" (p. 8).

Kate is a current, not ex-client (in comparison with Etherington, 2000). This means that issues arising may be processed in the relationship".

Voice off: We know that clients can defer to therapists, how do we know that Kate didn't defer to Deborah in this study?

(The screen displays messages from the enigmatic supervisor.)

(Before the research) 'Kate is a unique client. I believe she will benefit a lot from a deep reflective process and she will equally be able to decline things she does not want to do'.

(During the research): 'I listened to the research dialogue and noticed that while Deborah was in the role of researcher as well as being Kate's therapist, Kate remains Kate as she is in a therapy session; and Deborah had no difficulty in resuming only the therapist role afterwards'.

(After the research): 'While doing research will take a client in a direction that they aren't going in spontaneously, you'll see something therapeutically interesting come out of this collaboration!'

Deborah: There's, of course, a power dynamic here, in that I need to quote my supervisor's support of my decisions... But I also trusted my internal supervisor!

Act 2 
Noises off: POLICE SIRENS, CAR DOORS SLAMMING, PEOPLE SHOUTING (but no-one blinks an eyelid). A clock appears on the screen, and time passes very quickly.

(Two women appear in a soothing cream light.)

Deborah: (a professional statement, addressed to Kate).

'Until recently, I saw myself as a 'classical-client centred' (CCT) psychotherapistin-training.

I like CCT's political nature: Rogers (1978) talks of challenging inequalities (p. 273). I've also always liked "the model's elegant economy" (Barrett-Lennard, 1998, p. 104). It emphasises, as I do, the relationship (Merry, 2012, p. 21). I concur with Geller \& Greenberg (2002) that "presence" (being "fully there" [Schmid \& Mearns, 2006, p. 176]) is "the foundation of...empathy, congruence and unconditional positive regard" (p. 83).

I believe that being "genuine", "the more helpful [the relationship] will be" (Rogers, 1961, p. 33), and "the more acceptance and liking I feel towards [an] individual, the more I will be creating a relationship which [she] can use" (Rogers, 1961, p. 34); and I feel "a sensitive empathy with each of the client's feelings and communications" (Rogers, 1961, p. 34). Like Rogers (1961, p. 35), I believe in people's tendency to actualise. Like Franke, Rachlin \& Yip-Bannicq (2012), I notice that "nondirective therapy" "directs" (p. 205).

I agree with the CCT "rejection of diagnostic assessment and labelling" (Merry, 2012, p. 21); and I am increasingly confused by a perceived mismatch between this and Rogers' (1961) ideas of "psychological maladjustment" (p. 37). 
This has led me towards existentially-informed person-centred therapy. Above, Deurzen (2010) (a prolific tweeter) said: "existential therapy does not consider anxiety to be evidence of pathology, but rather an essential reminder of our vibrant and dangerous aliveness" (p. 238). I agree.

I'm increasingly questioning "certainties", so with any approach to therapy I'm aware how: "the theory's 'gaze' ... both opens up and reflects realities and closes down and deflects realities" (Goodman, 2016, p. 81). The most exciting work I read recently is Madison (2010), explaining an experiential-existential model. Madison (2010) says: "the body, rather than an inert object, is an experiential process interacting with and responding to its environment" (p. 192). As such, "therapists offer invitations to the client to stay with what is felt but not being paid attention to" (Madison, 2010, p. 196). This speaks to me'.

Kate (who is the only one qualified to assess the impact of Deborah's therapeutic responses): 'I've felt quite open to the way that you work, and kind of trust the way that you have worked with me, for it to work...'

(Then...we go back in time...)

\section{'Phase A: the beginning phase' (Barrett-Lennard, 1998, p. 106)}

Deborah (wrote notes after listening again to session 2, and Kate read them): 'I heard a lot of the processes [or interventions] that are still present. (They came naturally "embedded within a fluid, dialogical exchange" [Cooper, 2015, p. 73] rather than being "intents"): "active listening", (Cooper, 2015, p. 76) "if a therapist comes in too quickly... it may interrupt clients from connecting at [a deep] level"; "minimal encouragers" (Cooper, 2015, p. 76), "brief interjections that let clients 
know that they are being listening to, received and understood"; "reflecting, paraphrasing and summarising" (Cooper, 2015, p. 76) which show clients that "their experiences are intelligible" (Cooper, 2015, p. 77); and "asking open-ended questions" (Cooper, 2015, p. 78).

Deborah: '...you were sharing a lot with me (some types of therapists might have "asked for" what you said, to do an "assessment" ... my intention was not to "ask for" anything, only to receive whatever you wanted to say - your "assessment", in fact, of whether you wished to share with me) ...'

Kate: 'l've always felt very comfortable with you'.

Sexton et al (2010) comment: 'the early client-therapist connection was largely established in the first session. The level of the client-therapist connection was quite stable from the first to the second session' (p. 112).

Deborah: 'At 8.16 minutes into the session, you say (rather profoundly) that: "now is all we have" and observe that might sound "a bit poncey". You then tell me, laughingly, that "you're shaking your head", I say: "it's not poncey!", and you agree. It felt like there was already a connection developing between us'.

Barrett-Lennard (1998) observes that at the end of the 'beginning phase', there's a move from 'monologue to duologue... communicating with a person now felt and coming into view as a distinctive other person' (p. 107).

\section{The middle}

Deborah: 'Something that stood out for you [in our relationship] later? I know what mine is [laughing]'. 
Kate: 'You tell me what yours was [laughs]'. (Deborah: 'ok')

Deborah: 'There's a bit of self-disclosure in it, I hope that's going to be ok, and we can talk about it afterwards. I nearly didn't train for psychotherapy in case people brought a certain thing and there was a day when you did bring that thing and the relational depth [explored below] took over and I facilitated you saying more about the thing I probably didn't want to hear about and I think you cured me'.

Kate: [pause] 'Oh gosh. (Deborah: 'yes') I don't know what to say. (Deborah: 'mmm') Oh, I might cry. I feel quite emotional hearing that'.

Barrett-Lennard (1998) says: 'personal realness and transparency works to disarm and evoke trust in the other' (p. 113).

Deborah: 'Rapport/alliance building, assessment, interventions - they're ongoing processes. New patterns emerge from relating'.

'Phase D...clients now experience new levels of personal change' (BarrettLennard, 1998, p. 117).

Kate: 'There's been a lot of reflection on how some of the processes in me are changing, particularly this [deleted] element. And I remember when I first started coming to see you, that I couldn't put my finger on what I was missing (Deborah: 'mm'), it was almost like grasping at candy floss, or ether, and it's become clearer, it's become clearer what it was that was missing, and then what's happened is that I feel the [deleted] now, I'm more connected with it'. 
Barrett-Lennard (1998) observes, 'a helping relationship does not literally produce change but works by releasing or nourishing inbuilt recuperative and actualising tendencies' (p. 89).

Edgar (2008) observes that 'clocks' are a regular theatrical 'device', (p. 156) but here, time seems to be passing at the speed of light!

\section{Act 3}

Noises off: POLICE SIRENS, CAR DOORS SLAMMING, PEOPLE SHOUTING (but no-one blinks an eyelid). A clock appears on the screen, and time passes very quickly.

\section{Narrator:}

'Let's now fully unpack the meaning of the clocks and the noises off.

Geller \& Greenberg (2002) define "presence", as: "the ultimate state of momentby-moment receptivity and deep relational contact" (p. 85).

In Geller \& Greenberg's (2002) work, "therapists [from a variety of modalities] described actively clearing a space [for presence]" (p. 77). In "presence", therapists felt "flow, energy and calm" (Geller \& Greenberg, 2002, p. 80); "time and spatial boundaries seem[ed] to drop away" (Geller \& Greenberg, 2002, p. 81).

"[Presence] involves being with the client rather than doing to the client" (Geller \& Greenberg, 2002, p. 85); this raises questions about whether "presence" is really present in some of the modalities now explored. 
Geller \& Greenberg (2012) say that: Freud referred to "receptivity, and described it as emerging from an impartial, non-judgemental, evenly applied attention" ( $p$. $18)$; it was not communicated to the analysand. As we saw earlier, current psychodynamic work uses the relationship instrumentally. Gauna et al (2015) talk of "moments of high receptiveness" in clients, when therapists can "produce change" (p. 65).

CBT now also values how relationship affects outcomes (Geller \& Greenberg, 2012, p. 34) (see Friedberg, Tabbarah \& Poggesi [2013, p. 2] above). But Geller, Greenberg \& Watson (2010) compared "presence" in CBT, process-experiential and process-experiential/client-centred therapists; CBT therapists scored lowest (p. 607).

"Presence", in existential theory, "helps people confront, accept and tolerate...the inevitability of the conditions of living" (Tannen \& Daniels, 2010, p. 2). For Yalom and Bugental, "the cultivation of presence" (Krug, 2009, p. 330) "goes beyond, experiences or moments of deep connection with self and other" encompassing also "that each person's past is present in the here-and-now" (Krug, 2009, p. 331). Therapy then involves "connection" and recognition of "how specific behaviours and attitudes block [a client] from these deeper connections" (Krug, 2009, p. 331).

In person-centred therapy, Schmid \& Mearns (2006) say that: "we are looking for a deeper sense of meeting than simply a working alliance" (p. 178). For Focusingoriented therapists, "presence of the therapist is central to clients who are learning to listen to their own emotional experience" (Geller \& Greenberg, 2012, p. 29-30). Geller \& Greenberg (2012) note that: "even though humanistic 
therapists espouse the value of presence, they have not clarified how to be fully present” (p. 34).

Geller (2013) feels that therapist "presence"/inviting client "presence" "can allow for moments of relational depth" (p. 175). Variations of "relational depth" occur across modalities (Wiggins, Elliott \& Cooper, 2012, p. 140). Mearns \& Cooper (2005), person-centred therapists, define "relational depth" as "a feeling of profound contact and engagement with a client" (p. 1); it is "fundamentally dyadic" (Mearns \& Cooper, 2005, p. 113); it can be "moments" or "enduring experiences" (Mearns \& Cooper, 2005, p. 1)'.

Kate: (to whom Deborah had previously said she didn't notice time passing in their meetings, and who had just read some notes about 'relational depth' written by Deborah) 'So, it's a "thing”!' [Deborah: 'mmm!'] [both laugh].

\section{Narrator:}

'Wiggins, Elliott \& Cooper (2012) contend that there being a "timeless atmosphere" seemed to be about "moments" only (p. 150)'.

Deborah: 'The reason I put bold around 'enduring' (in the notes), is because that's the one they don't write about as much, but that is what I feel here, it's not every now and again, to me, if feels enduring. I don't know how it is for you?'

Kate: 'l'm not aware of what's happening outside, not aware of anything else'.

\section{Narrator:}

'Knox \& Cooper (2011) say that their interviewees compared experiencing relational depth with not experiencing it with previous therapists (p. 68)'. 
Kate: 'Whereas all the other times [of having person-centred therapy], yes l've connected with people on a level, and, you know, l've got a lot from it, it's not been the same connection, I don't think, as it has been with us'.

\section{Narrator:}

'When relational depth didn't happen for clients: "a recurring theme was the unwillingness of the client to 'let go'" (McMillan \& McLeod, 2006, p. 288)'.

Deborah: 'I wrote that (on the materials Kate read) because there were a few sessions where you said you were censoring... I was thinking [pauses] perhaps this [what has been written before] isn't quite right, that you can still be censoring and still have relational depth, there can still be some things that you're thinking how you can say it for your own...'

Kate: '...safety, yes'.

Deborah: 'Yes, and it doesn't mean you can't have connection. They might have missed something'.

Kate: '... when l've been holding things back, it's not been because I don't t-rust you, it's maybe because I don't trust myself with it, what those feelings mean and then get carried away with it, and open Pandora's box....But, that doesn't mean to say that I'm not engaged'.

Bazzano (2014) observes of ideas of clients not 'letting go' that: 'the therapist's frustration can be a great teacher' (p. 210).

\section{Narrator:}


(She throws her script aside): 'Deborah and Kate, I find your interpretation more interesting!'

Kate: '...that's a whole other paper!'

Deborah: 'It is!' [both laughing].

\section{Narrator:}

"Bazzano (2014) introduces the term "togetherness", referring to "aloneness, autonomy and conflict alongside relatedness and interdependence"' (p. 205).

(Off-script again; she's building up her part.) 'That doesn't jettison relational depth, and it offers the existentially-informed approach that you're developing, Deborah'.

AM: "Doesn't time fly?"

\section{Epilogue}

\section{Narrator:}

'When Deborah and Kate reflected upon their research dialogues, something interesting happened...'

Deborah: 'We've been doing what we do, but before [this process], we hadn't sort of done a review of how we are doing it, to me it feels a very helpful thing to know more about how you feel about it'.

Kate: 'Yes, definitely. I've had quite a lot of counselling and stuff and I've not had that kind of dialogue'. 
Deborah: 'Would you like for us to reflect on being together more often?'

Kate: 'Yes, maybe, yes, I think that would be good'.

Deborah: 'How would you like that to be initiated?'

Kate: 'Shall we do it every month. Does that sound ok?'

\section{Narrator:}

'Bond (2013) distinguishes between therapy/research, contending that research "is primarily for the benefit of people other than the patient" (p. 338). As has just been shown, that need not necessarily be so.

This outcome suggests a pluralistic framework. Cooper \& McLeod (2007) explain that it: "maintains that the client's view on what is helpful and not helpful in therapy is as valid as the therapist's" (p. 139).

This development is available to Deborah and Kate because of Deborah's personal work on "certainties" - previously she would have been too "classical client-centred" for "reviews"!'

\section{Deborah:}

'l've written this case study in a way that might not have been expected, as a piece of $A B R$ in which Kate and I collaborated.

Leavy (2015) explains that evaluation of ABR provokes "much debate" (p. 266), with people considering if it should be assessed like qualitative work, or if something different is needed. 
Leavy (2015, p. 267) is opposed to a "gold standard" of evaluation for ABR, for she judges assessment of ABR to be "a messy terrain" (Leavy, 2015, p. 268).

Nevertheless, Leavy (2015, p. 266) says that "there is no question that we need ways to evaluate this work". Evaluation methods may reflect researchers' locations in the sciences/arts (Leavy, 2015, p. 267-8) and are outlined in Leavy (2015, pp. 266-289).

Earlier, McLeod's (2010, p. 203) misgivings about "autobiographical and fictional narrative case studies" were cited. Those preferring more usual "case studies" may be challenged by the collaborative approach and the ABR here. But, as Leavy (2015, p. 285) observes: "no research product can be all things to all people".

Taking Leavy's (2015, p. 267) advice that any "individual criteria" for evaluation need to be applied "as appropriate to a specific project", I follow Leavy (2015, p. 273) in being particularly drawn to the concept of "usefulness" as a means of evaluating this present work.

I perceive (as explained above) that psychotherapy "case studies" usually tend to define people attending by their "problems" and psychotherapists by their training/experience, and that this creates flat/objectified characters, an "us" and "them" situation of deep inequality - in which some people are deficient and others "fix" them - rather than revealing complex human beings who have more in common than might be supposed. Such writings create a sterility to psychotherapy which does not resonate with me, and a situation in which I feel "ethical practice" (Leavy, 2015, p. 280) is compromised. 
In contrast, in collaborating with Kate to explore our sessions together and drawing on that material here, I hope the warmth of the encounter between us two "multi-dimensional" (Leavy, 2015, p. 281) human beings has been shown. In editing this work for publication, I have repeatedly agreed with Meekums (2011) that ABR provokes "emotional/embodied reactions" (p. 382): I have felt/feel deep honour and pleasure that I meet with Kate. And if I have been able to convey at least some of the warmth of the relationship and its relating then this is primarily, for me, how this work should be evaluated - a "usefulness" (Leavy, 2015, p. 272) which I would also hope might influence ethical principles in psychotherapy "case study" research (see Leavy's [2015, p. 274] comments on influencing policy) for I feel that psychotherapists need to take all opportunities available to stop seeing "clients" as "other", including in writing; I believe that ABR has enabled me to start to develop this "research goal" (Leavy, 2015, p. 273).

Bourriaud (1998) says art has a "co-existence criterion ...does this work permit me to enter into dialogue?" (p. 1089). Bringing many voices on-stage, I sought/seek to encourage the voices of you, the audience, maybe particularly those of you who are in psychotherapy training or delivering it. Might you conceive of "case studies" differently through this arts-based research?'

(The curtain falls.) 


\section{References}

Abrahams, H. (2007). Ethics in counselling research fieldwork. Counselling and Psychotherapy Research, 7(4), 240-244. doi: 10.1080/14733140701707068

Adame, A. \& Leitner, M. (2011). Dialogical constructivism: Martin Buber's enduring relevance to psychotherapy. Journal of Humanistic Psychology, 51(1), 41-60. doi:10.1177/0022167810379959

Ayckbourn, A. (2002). The crafty art of playmaking. London: Faber \& Faber.

Barrett-Lennard, G. (1998). Carl Rogers' helping system. Journey and substance. London: Sage.

Bazzano, M. (2014). Togetherness: intersubjectivity revisited. Person-Centred \& $\begin{array}{lll}\text { Experiential } \quad \text { Psychotherapies, } & \text { 13(3), }\end{array}$ doi:10.1080/14779757.2013.852613

Bond, T. (2013). The ethics of research. In Carroll, M. \& Shaw, E. (2013) Ethical maturity in the helping professions. London: Jessica Kingsley.

Bourriaud, N. (1998). Relational aesthetics. Les presses du reel.

British Association for Counselling and Psychotherapy (BACP) (2016). Ethical framework for the counselling professions. [Online] Available from:

http://www.bacp.co.uk/ethics/EFfCP.php

Carroll, M. \& Shaw, E. (2013). Ethical maturity in the helping professions. London: Jessica Kingsley.

Collins, P.H. \& Bilge, S. (2016). Intersectionality. Cambridge: Polity. 
Cooper, M. (2003). "I-I" and "I-Me": transposing Buber's interpersonal attitudes to the intrapersonal plane. Journal of Constructivist Psychology, 16, 132-153. doi: $10.1080 / 10720530390117911$

Cooper, M. \& McLeod, J. (2007). A pluralistic framework for counselling and psychotherapy. Counselling and Psychotherapy Research, 7(3), 135143. doi:10.1080/14733140701566282

Cooper, M. (2015). Existential psychotherapy and counselling: Contributions to a pluralistic practice. London: Sage.

Deurzen, E. V. (2010). Everyday mysteries. London: Routledge.

Edgar, D. (2009). How plays work. London: Nick Hern Books.

Elliott, R. (1986). Helpful and non-helpful events in brief counselling interviews: an empirical taxonomy. Journal of Counselling Psychology, 32(3), 307-322.

Etherington, K. (2000). Narrative approaches to working with adult male survivors of child sexual abuse. London: Jessica Kingsley.

Franke, M., Rachlin, H. \& Yip-Bannicq, M. (2012). How nondirective therapy directs: The power of empathy in the context of unconditional positive regard. Person-Centred \& Experiential Psychotherapies, 11(3), 205-214. doi: $10.1080 / 14779757.2012 .695292$

Friedberg, R., Tabbarah, S. \& Poggesi, R. (2013). Therapeutic presence, immediacy and transparency in CBT and youth: carpe the moment! The Cognitive Behaviour Therapist, 6(12), 1-10. doi: 10.1017/S1754470X13000159 
Gabriel, L. \& Casemore, R. (2009). Introduction. In Gabriel, L. \& Casemore, R. (Eds.) Relational ethics in practice. London: Routledge.

Gauna, M., Roibal, M., Ruiz, J., Fernandez, J. \& Bleichmar, H. (2015). Active change in psychodynamic therapy: moments of high receptiveness. American Journal of Psychotherapy, 69(1), 65-86.

Geller, S. (2013). Therapeutic presence as a foundation for relational depth. In Knox, R., Murphy, D., Wiggins, S. \& Cooper, M. (Eds.) Relational depth. Basingstoke: Macmillan.

Geller, S. \& Greenberg, L. (2002). Therapeutic presence: therapists' experience of presence in the psychotherapy encounter. Person-Centred \& Experiential Psychotherapies, 1(1-2), 71-86. doi: 10.1080/14779757.2002.9688279

Geller, S. \& Greenberg, L. (2012). Therapeutic presence. American Psychological Association.

Geller, S., Greenberg, L. \& Watson, J. (2010). Therapist and client perceptions of therapeutic presence: the development of a measure. Psychotherapy Research, 20(5), 599-610. doi: 10.1080/10503307.2010.495957

Gergen, M. \& Gergen, K. (2011). Performative social science and psychology. Forum: Qualitative Social Research, 12(1), 1-11.

Goodman, D. (2016). The McDonaldization of psychotherapy: processed foods, processed therapies and economic class. Theory and Psychology, 26(1), 77-95. doi:10.1177/0959354315619708 
Jacobson, G. (2000). Case presentation - a perfect transference. Psychoanalytic Social Work, 7(3), 3-18. doi: 10.1300/J032v07n03_02

Jones, K. (2006). A biographic researcher in pursuit of an aesthetic: the use of arts-based representations in "performative" dissemination of life stories. Qualitative Sociology Review, 11(1), 66-85.

Knox, R. \& Cooper, M. (2011). A state of readiness: an exploration of the client's role in meeting at relational depth. Journal of Humanistic Psychology, 51(1), 6181. doi:10.1177/0022167810361687

Krug, O. (2009). James Bugental and Irvin Yalom: Two masters of existential therapy cultivate presence in the therapeutic encounter. Journal of Humanistic Psychology, 49(3), 329-354. doi:10.1177/0022167809334001

Lago, C. \& Christodoulidi, F. (2013). Client-therapist diversity: Aspiring towards relational depth. In Knox, R., Murphy, D., Wiggins, S. \& Cooper, M. (Eds.) Relational Depth. Basingstoke: Macmillan.

Leavy, P. (2015). Method meets art: Arts-Based research practice. New York: Guildford Press.

Macleod, R. \& Elliott, R. (2014). Non-directive person-centred therapy for social anxiety: a hermeneutic single-case efficacy design study of a good outcome case. Person-Centred \& Experiential Psychotherapies, 13(4), 294-311. doi: $10.1080 / 14733145.2011 .546203$

Madison, G. (2010). Focusing on existence: five facets of an experientialexistential model. Person-Centred \& Experiential Psychotherapies, 9(3),189-204. 
McLeod, J. (2010) Case study research. London: Sage.

McMillan, M. \& McLeod, J. (2006). Letting go: The client's experience of relational depth. Person-Centred \& Experiential Psychotherapies, 5(4), 277-292. doi: $10.1080 / 14779757.2006 .9688419$

Mearns, D. \& Cooper, M. (2005). Working at relational depth in counselling and psychotherapy. London: Sage.

Meekums, B. (2011). Editorial. British Journal of Guidance and Counselling, 39(5), 379-384. doi: 10.1080/03069885.2011.617146

Merry, T. (2012). Classical client-centred therapy. In Sanders, P. (Ed.) The Tribes of the person-centred nation. Ross-on-Wye: PCCS Books.

Rogers, C. (1951). Client-centred therapy. London: Constable.

Rogers, C. (1961). On becoming a person. London: Constable.

Rogers, C. (1978). Personal power. London: Constable.

Saldana, J. (1999). Playwriting with data: ethnographic performance texts. Youth Theatre Journal, 13(1), 60-71. doi: 10.1080/08929092.1999.10012508

Samuels, A. (2015). A New therapy for politics? London: Karnac.

Sexton, H., Littauer, H., Sexton, A. \& Tommeras, E. (2005). Building an alliance: early therapy processes and the client-therapist connection. Psychotherapy Research, 15(1-2), 103-116. 
Schmid, P. \& Mearns, D. (2006). Being-with and being-counter: person-centred psychotherapy as an in-depth co-creative process of personalisation. PersonCentred \& Experiential Psychotherapies, 5(3), 174-190.

Shorey, R. \& Stuart, G. (2012). Manualised cognitive-behavioural treatment of social anxiety disorder: a case study. Clinical Case Studies, 11(1), 3547. doi: $10.1177 / 1534650112438462$

Stephen, S., Elliott, R. \& Macleod, R. (2011). Person-centred therapy with a client experiencing social anxiety difficulties: a hermeneutic single case efficacy design. Counselling and Psychotherapy Research, 11(1), 55-66. doi: $10.1080 / 14733145.2011 .546203$

Tannen, T. \& Daniels, M.H. (2010). Counsellor presence: bridging the gap between wisdom and new knowledge. British Journal of Guidance and Counselling, 38(1), 1-15. doi: 10.1080/03069880903408661

Wiggins, S., Elliott, R. \& Cooper, M. (2012). The prevalence and characteristics of relational depth events in psychotherapy. Psychotherapy Research, 22(2), 139-158. doi: 10.1080/10503307.2011.629635

Willis, A., Bondi, L., Burgess, M.C., Miller, G. \& Fergusson, D. (2014). Engaging with a history of counselling, spirituality and faith in Scotland: a readers' theatre script. British Journal of Guidance and Counselling, 42(5), 525-543. doi: 10.1080/03069885.2014.928667

Worsley, R. (2006). Emmanuel Levinas: resource and challenge for therapy. Person-Centred \& Experiential Psychotherapies, 5(3), 208-220. doi: $10.1080 / 14779757.2006 .9688410$ 
Yalom, I. (2002). The gift of therapy. London: Piatkus.

Zeldin, T. (2015). The hidden pleasures of life. London: Quercus. 